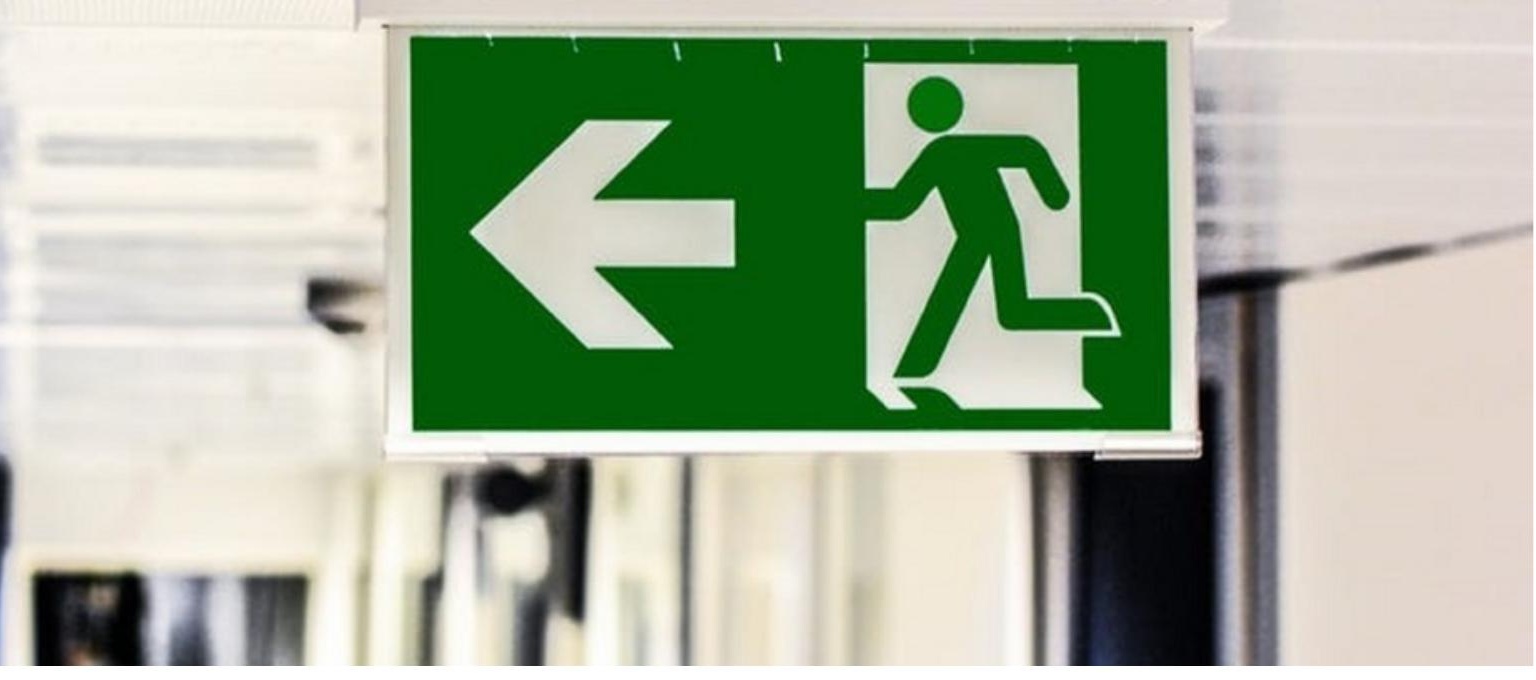

Immigration Policy in Malaysia and my eight horrendous Days in Detention

Authors: $\quad$ Mike Omilusi

Submitted: $\quad$ 24. August 2019

Published: $\quad$ 27. August 2019

Volume: 6

Issue: 8

Affiliation: $\quad$ Department of Political Science. Ekiti State University, Nigeria.

Languages:

Keywords:

Categories:

DOI:

English

Immigration, Malaysia Policy, Detention, Experience.

Humanities, Social Sciences and Law

10.17160/josha.6.8.595

Abstract:

I am a political scientist and in the course of my career as a lecturer and pro-democracy activist, I have traversed over 50 countries across different continents. Hence, I had taken the routine details of international travel for granted - until my traumatic experience in Malaysia where I was detained under extremely dehumanizing conditions for eight days in November 2017. My offense was that I failed to get a transit visa to go from one airport in the country to another. About the Author: Dr. Mike Omilusi is an Independent Democracy Monitor, Freelance Journalist, Development Worker, and University Teacher in Nigeria. 


\title{
Immigration Policy in Malaysia and My Eight Horrendous Days in Detention
}

\author{
Dr. Mike Omilusi ${ }^{1}$
}

\section{Preamble}

I am a political scientist and in the course of my career as a lecturer and pro-democracy activist, I have traversed over 50 countries across different continents. Hence, I had taken the routine details of international travel for granted - until my traumatic experience in Malaysia where I was detained under extremely dehumanizing conditions for eight days in November 2017. My offense was that I failed to get a transit visa to go from one airport in the country to another.

I admit up front that my travel agency shared the blame in the fiasco in that it failed to abide by a legal fact too obscure to the ordinary traveler, but the Malaysian authorities were guilty of applying the immigration laws of their country in abrogation of common sense. Let me explain. The Malaysian capital, Kuala Lumpur, has two airports (KLIA 1 and KLIA 2) designed for international flights; sometimes, passengers in transit are required to move from one airport to the other. To do this, one needs a Malaysian visa. This is normal. What is abnormal is that unlike in other countries, Malaysia does not issue visa on demand at its airports, even for passengers who have no business whatsoever in the country beyond boarding a plane at the second airport. It is noteworthy that on the way to Nigeria from Malta in January 2017, I was issued a 24-hour transit visa at the Heathrow airport in London.

Owing to this anomaly in Malaysia, scores of travelers are daily caught in a trap in which immigration officials subject them to mental and emotional torture while extorting money from the hapless people caught in this web of calcified bureaucracy.

\footnotetext{
${ }^{1}$ Dr. Mike Omilusi is an Independent Democracy Monitor, Freelance Journalist, Development Worker, and University Teacher in Nigeria
} 
I was travelling to attend some conferences related to my work as an academic. It was supposed to be a routine journey, though long and probably tedious as it spanned four Continents - Africa, Asia, Australia, and Europe. I arranged with my travel agent for one-way tickets for each leg of the trip. I had no inkling of any possible problem as I juggled the logistics in the face of financial constraints.

I was attending the Lien International Conference on Good Governance, organized by the Nanyang Centre for the Public Administration from the Nanyang Technological University (NTU), Singapore (October 27-28, 2017); the 6th Ingram Colloquium organized by the University of New South Wales, Sydney, Australia (November 2-3, 2017); and another conference at the University of Malta (November 16th and 17th 2017). I left Nigeria on October 25, 2017 for Addis Ababa, from where I proceeded to Singapore. The other two legs of the trip - to Singapore and Australia - went smoothly, and I was looking forward to working on my papers for future publication. I left Sydney, Australia, on November 6 en route Malaysia with the hope of taking the last leg of the trips to Europe.

\section{Arrival in Kuala Lumpur Hell}

After a nine-hour flight, we landed at Kuala Lumpur Airport, KLIA 2 around 8.25 pm from where I was meant to transit to Europe three hours later. This was not to be. At the last checkpoint where I was to pick my luggage and proceed to the appropriate terminal, the officers on duty told me that I could not proceed from that point unless I had a Malaysian visa because, according to them, "going to terminal 1 (KLIA 1) will require that you pass through the country which cannot be allowed without you having a Malaysian visa". They referred me to the immigration crew not far from the counter - thus began my ordeal in Malaysia.

I explained to a senior officer that I had to leave the country that night; that I was just on transit to Europe; that I had no business in Malaysia and was prepared to bear the additional expense involved in getting a transit visa at the airport. All fell on deaf ears. The officer declared bluntly: "You will be deported to Australia because they shouldn't have sent you here in the first instance without a visa". Aghast, I aspirated, "Oh, my God!", and this seemed to inflame the man further. He advised me not to involve God in my predicament and the mistakes arising from my travel agent who ought to have known that the Turkish airline I was supposed to board only operated from the other terminal (KLIA 1).

At this point, it occurred to me that my travel agent was remiss in her obligations. When I contacted her, she could only express alarm and regret - pretty useless emotions in the circumstances. But then it was equally obvious that the AirAsia that brought me from Australia put profit in front of its responsibilities to passengers for it did a thorough checking on my documents and was aware that I would just be at Kuala Lumpur on transit as indicated in my flight ticket. I later discovered on the 
airline's website that it was aware but chose to leave its passengers to the vagaries of Malaysia's immigration policy. I pleaded to be given a transit visa at KLIA 2 to enable me move to KLIA 1 since I was spending just a few hours in the country and I had no business outside the airports. The officials repeated what had become a formulaic response to the victims of their obnoxious policy; that the normal procedure was to send me to Australia (or wherever the victim had come from); then Australia would reject me again and indicate that on my documents; then the Malaysian immigration would now prepare my deportation to my home country. I was speechless but worse was to come!

\section{Man's Inhumanity to Man in the Name of Immigration Policy}

I was taken to an office where I met a few travelers with the same problem. The unfriendly officials, who kept muttering "normal procedure" in response to every query, seized all electronic gadgets from their unwanted guests. My phone, laptop, wristwatch etc. were taken into their custody alongside my hand luggage. Next, I was ordered to remove my belt and, instantly, I remembered prison inmates I used to see in Nigerian jails (while working with a charity organization as part of our prison apostolate program). Suddenly, I was transformed from a hopeful, go-getter academic and development worker into a prisoner thrown in a cell of undifferentiated humanity united in humiliation and anguish! The next eight days were the most horrendous I have ever experienced.

\section{The Detention Centre}

It was an underground cell, about 25 by 20 feet in size. In that space little bigger than my office at the Ekiti State University, Ado-Ekiti, was crammed over one hundred people - I counted 115 on being pushed into the hellhole but the figure fluctuated as people gained their freedom and other victims took their place. The mass of humanity stood or squatted all day, with barely enough breathing space for each person. At night, there was no space to lie down; for the first three days, I stood or squatted on a spot. Some slept one atop the other on the bare floor out of exhaustion.

A robust sliding door led to this cage, with a barrier of metal on one wall overlooking the immigration office where there was a toilet for the detainees. With so many people having to use the facility, the stench from it was overpowering, especially mixed with the smell of stale sweat, unwashed mouths, the contrasting odors of various racial groups, and the rank putridness of dirty socks. This was the hell in which the Malaysian authorities served an unvarying dish of rice three times a day. For the first couple of days, I could not bring myself to eat but logical self-preservation prompted me to take the stuff once a day to keep up my strength.

The cell paraded an amalgamation of different races and countries, mostly from Asia. Indians always constituted the highest number. The first night, I met two Sudanese - 
students in Malaysia - who were denied entry to complete their studies. Even with the language barrier, the inmates communicated empathy and treated one another with courtesy.

As if the environment was not brutal enough, the officials harassed and molested inmates - at times for asking questions or not responding with alacrity when called to take food or simply for questioning the rationale for undue incarceration. Naturally, the system lent itself to rampant corruption. Every day, a junior officer would stand by the iron grating separating the cell from the office, his ID card tag turned backward to conceal his identity. Pretending to be offering help, he would approach identified group leaders (most of the Asian detainees came in groups) who would thereafter collect money from other members. Perhaps this was the reason why wallets were not confiscated alongside our other belongings. The members of one such group coughed up 300 Ringgit (the Malaysian currency; about 30,000 Naira) each. I was in the doldrums.

For the first 24 hours, I was mentally paralyzed because I did not know how to process the situation; it all felt so surreal. In many ways, it was worse than being imprisoned in that a criminal at least anticipates the sentence while on trial. In my case, it was straight from freedom to jail without any preliminary or just cause. Then, for someone whose life and career involve constant thought, research, communication, deadlines, etc., it was to me, maddening to be deprived of the means for carrying out all of this. I was surrounded by a mass of humanity but it was as if I was in solitary confinement. The degradation we were all subjected to was so unnecessary in this day and age. I saw many decent and responsible gentlemen threw into the cell on flimsy excuses. I saw octogenarians traveling to visit loved ones spending five days in the abode of horror, pending when "procedure" would be duly followed.

\section{The Long Road to Freedom}

The detainees were discharged in batches, depending on availability of flights once the document rectification procedures were completed. It could be five, ten or even fifteen people at a time. Such release from cell could take place once, twice or thrice daily with everyone eager to hear his (females were detained in another cell) name in the next announcement. A day after I came in, two of the friends I had made there - a Filipino and Sudanese - were released and I scribbled my wife's phone number for them to contact.

On the fifth day, I became the longest-serving inmate. This became manifest when I was the first person to be called during breakfast. As usual, I was called by country name and others began to re-echo, "Nigeria! Nigeria!" Later that day, the officials started calling me Michael; familiarity had set in. I had thought my going back to Australia would not take more than a day or two. Now, each day dawned with horror and uncertainty. Two days earlier, my wife had contacted me on the landline of the 
immigration office, having been briefed about my condition by the Filipino friend. Although as depressed and flabbergasted as I was, she was upbeat about the steps she was taking to reach out to people. She impressed upon me the efficacy of prayers in such circumstances. I was not alone after all!

My wife contacted the Nigerian community in Malaysia for possible intervention; she also reached out to the Nigerian embassy. Phone calls she made to the Malaysian immigration officials were subsequently rejected. The Nigerian community, with officials of the Nigerian embassy, I later learned, sent a delegation to the immigration office at the airport on November 14, the morning after my release. I appreciate the intervention of Senator Babafemi Ojudu in this regard.

Several attempts were made to deport me to Australia as planned. On the 10th of November, one of the officials told me that that I could be escorted to Terminal 1 that day and proceed to Europe. I was allowed to contact my travel agents who had earlier, after our first discussion on November 6, canceled the flight. She re-scheduled my flight to reflect Malaysia to Malta and thereafter, I was expecting my release for the $10.45 \mathrm{pm}$ flight. This was when another official told me that it was impossible and that the other officers did not tell me the right procedure. That word again!

The following day, November 11, I was woken up around $10.30 \mathrm{pm}$ and informed of my imminent departure with an AirAsia flight they had arranged. My luggage and gadgets were returned to me. Seven senior officers, now unusually friendly, escorted me from their office to the departure gate in a trek of 14 minutes. But alas, as we got there, the aircraft was just leaving. I could see the disappointment on their faces and one of them announced: "Michael, I am sorry, you have to spend the night in the cell tonight, we make another booking tomorrow".

On November 12, an agent of AirAsia came in the afternoon, proposing another option of being flown to Europe en-route Iran (specifying some conditions like a minimum of 300 US Dollars as travel entry). That idea was later dismissed and by evening, I was informed that the Regional Manager of AirAsia would personally fly with me to Australia to ease my passage. I was relieved and other detainees who had learned about the development started congratulating me. When I could not see any sign of departure by $10 \mathrm{pm}$ for the 11.45 flight, I became restless and began banging the iron partition. This attracted a female official who told me the manager was indisposed and had postponed the journey till the following day.

On November 13, having been shown the new ticket, I was awake throughout. At $10.30 \mathrm{pm}$, I was called out to pick my luggage again. Goodbye, Malaysia. We got to Australia on November 14 and I commenced my journey to Europe via Abu Dhabi (United Arab Emirates) and Nigeria in a 28-hour journey. 


\section{Can the Impunity by the Malaysian Authorities be Challenged?}

It is likely that the human rights abuses hiding as immigration policy in Malaysia persist if it is unchallenged legally and the victims do not have the weight of any organization behind them. Not knowing exactly how I might pursue justice, I reported the matter to Amnesty International (Amnesty UK) but they told me, "Amnesty International is unable to provide legal advice; you will need to contact solicitors in Nigeria or Malaysia." Needless to say, I cannot afford the cost of such inter-continental litigation or the diplomatic hurdles it would involve. Perhaps it would be different if I were an American for I could see the tort lawyers coming to my aid. Still, someone should teach the Malaysian authorities a lesson in how not to treat innocent passengers using their airports.

\section{Streamlining Travel Worldwide}

In an era where the concept of the world as a village is real in terms of communication and speed of transportation, surely the global community should move towards streamlining immigration policies to eliminate the kind of assault on human dignity and freedom as I experienced in Malaysia. I understand that part of the problem is the increasing erosion of trust by criminals and dishonest people who take advantage of loopholes in systems and procedures. Nonetheless, while recognizing the sovereign right of every nation to manage its own policy on international travel, there should be in-built flexibility to accommodate innocent people caught in the incompetence of others. 
Journal of Science, Humanities and Arts

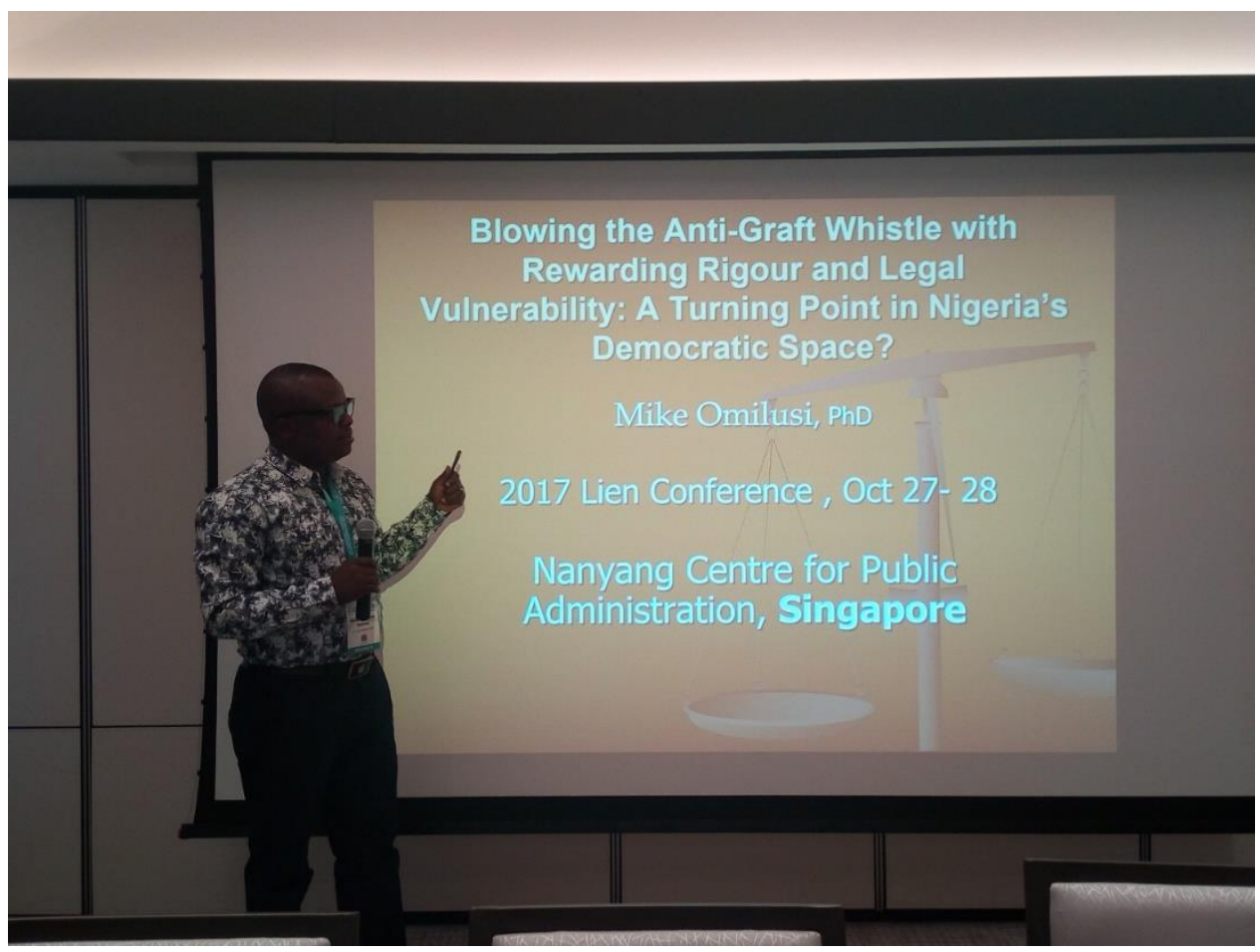

Presenting my

paper at the conference in Singapore

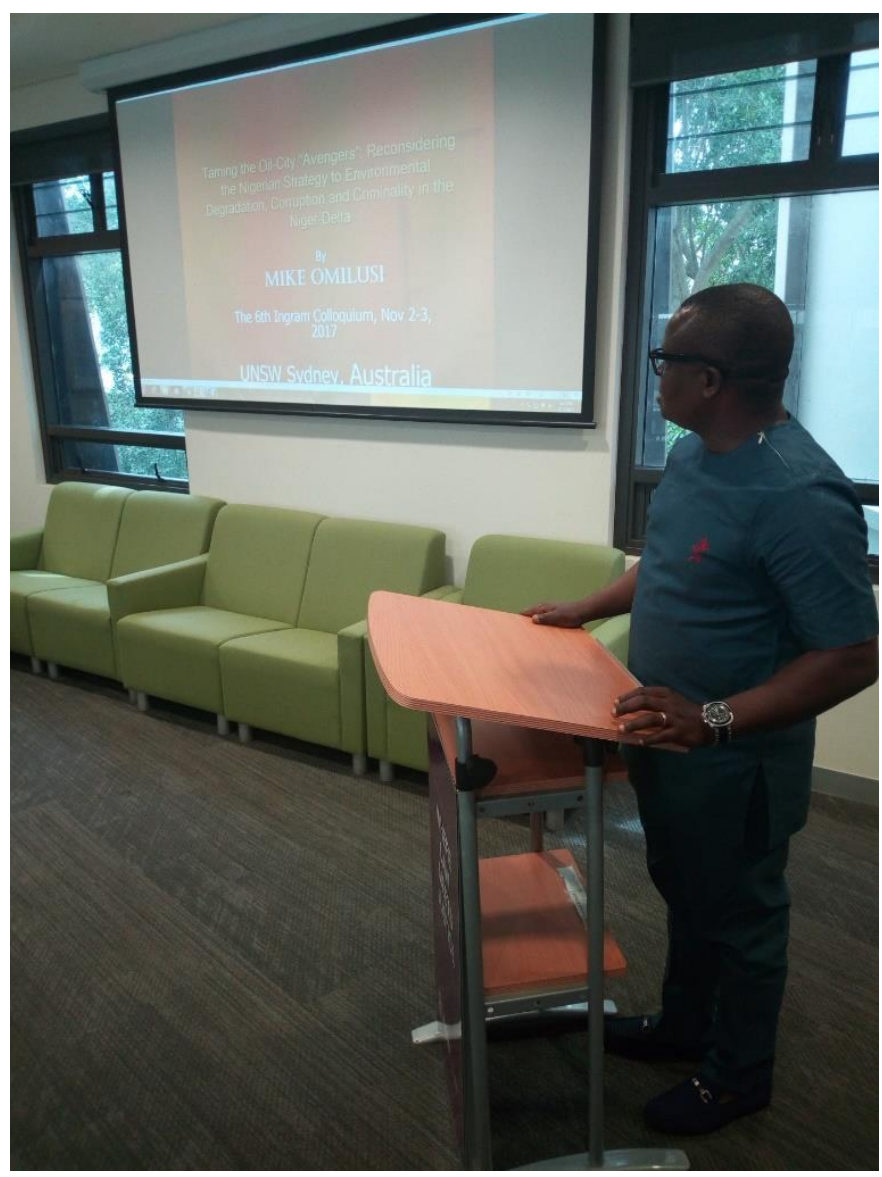

Presenting my paper at the conference in Australia 